\title{
LA LIBERTAD SEGÚN GUIZOT
}

\section{THE FREEDOM ACCORDING TO GUIZOT}

\author{
Manuel Carbajosa Aguilera \\ Universidad Pablo de Olavide
}

\begin{abstract}
SUMARIO: I. INTRODUCCIÓN.- II. TEORÍA DE LA LIBERTAD LIMITADA EN GUIZOT. 2.1. La libertad natural y la libertad en sociedad: el ataque a la voluntad individual.- 2.2. La libertad en sociedad: el imperio de la razón trascendente al servicio de unos pocos. El ataque a la razón subjetiva.- III. UNA LIBERTAD AL SERVICIO DE LA GOBERNABILIDAD.- IV. LA SEGUNDA LEGITIMIDAD DE LA LIBERTAD LIMITADA: EL GRADO DE CIVILIZACIÓN.- V. CONCLUSIONES.
\end{abstract}

Resumen: Este artículo aborda la posición conflictiva, y sin embargo central, del concepto de libertad en el pensamiento político de François Guizot. Se trata de una libertad limitada, fiel al recelo que el autor manifiesta hacia la libertad del individuo en la nueva sociedad contemporánea. Analizamos cómo Guizot, en su propósito de esclarecer la incógnita de la libertad, la reduce dialécticamente a una limitada libertad a disposición de la élite de los capaces.

Abstract: This article explains the conflicting, yet central, position of the concept of freedom in the political thought of François Guizot. This is a limited freedom, faithful to the author's misgivings about the freedom of the individual in the new contemporary society. We analyze how Guizot, in his purpose to clarify the unknown of freedom, reduces it dialectically to a limited freedom at the disposal of the elite of the capable.

Palabras clave: Libertad limitada, Guizot, pensamiento político, liberalismo doctrinario.

Key Words: Limited freedom, Guizot, political thought, doctrinaire liberalism.

\section{INTRODUCCIÓN.}

En el marco de la Restauración francesa se desarrolla un proceso de reflexión iniciado en Termidor en torno a la necesidad de limitar el concepto de libertad, motivado, fundamentalmente, por la asimilación del Terror a la idea de su desbordamiento -incongruencia no obstante interesada, pues, si algo idealizó la dictadura jacobina fue la virtud revolucionaria, no así la libertad-. Conscientes de la encrucijada de la Historia, los franceses habían comprendido a la altura de 1814 que toda vuelta al pasado, por deseada que pudiera ser para una parte de la población - principalmente para los emigrados-, resultaba imposible, puesto que la propia sociedad francesa había experimentado unos profundos cambios que habian arraigado y significativamente la nueva élite nacida de la Revolución y el Imperio había consolidado un predominio social al que no estaba dispuesta a renunciar (vid. p. ej. el art. 6 del Proyecto de Constitución elaborado por el Senado, de 6 de abril de 1814). Las élites emigradas asumian que para posibilitar el retorno de Luis XVIII al trono de 
Francia era necesario, en principio y como tributo ineludible, ceder a la aceptación estratégica de aquella nueva notabilidad, dada la fuerza de los hechos, reservando su rencor para momentos más propicios. La postulación de la legitimidad, que formalmente apelaba a la solidez de la Historia, en realidad estaba apuntalada sobre compromisos y renuncias muy precarios, de tal modo que bajo las palabras solemnes el espíritu de confrontación irá arrumbando, carcomiendo, al espejismo del compromiso. A fin de cuentas, como Chateaubriand dejó escrito, y en ello coincidirá Guizot, la Carta no era sino un tratado de paz entre los dos partidos que dividían a los franceses. Y es que la propia Carta contenía en sí misma la tensión esencial de la Restauración entre el principio monárquico de la letra del texto y el principio representativo de su espíritu, principios no necesariamente antitéticos, como señala Lacchè, pero tampoco abocados de forma natural a la conciliación, lo que dificultaba tanto la tarea de clausurar el ciclo revolucionario, como la de instaurar y consolidar un sistema politico donde pudieran convivir la monarquía y las nuevas libertades ${ }^{1}$.

Convencidos de que el retorno al Antiguo Régimen resultaba imposible ${ }^{2}$, la nueva élite comprende, por su parte, que el gran peligro contemporáneo le llega de abajo, ante lo cual despoja a su liberalismo de toda utopía insurreccional, planteando, entre otros aspectos, una revisión profundamente crítica de la libertad, una libertad útil allá en 1789, pero subversiva para los nuevos tiempos y los nuevos intereses. Este liberalismo a la defensiva, de consolidación y no de derribo, se convence de que el orden es la condición previa de la libertad ${ }^{3}$. Ante

1 Vid. p. ej. Guillaume de Bertier de Sauvigny, La Restauration, Flammarion, París, $3^{\mathrm{a}}$ ed., 1974 (trad. al español, La Restauración, Pegaso, Madrid, 1980). Emmanuel de Waresquiel y Benoît Yvert, Histoire de la Restauration (1814-1830). Naissance de la France moderne, Perrim, Paris, 1996. Emmanuel de Waresquiel, L'histoire à rebrousse-poil. Les élites, la Restauration, la Révolution, Fayard, París, 2005. Francis Démier, La France de la Restauration (1814-1830). L'impossible retour du passé, Gallimard, París, 2012. François-René de Chateaubriand, Réflexions politiques sur quelques écrits du jour et sur les intéréts de tous les Français, Le Normant, Paris, 1814, p. 44. Pierre Rosanvallon, La monarchie impossible. Les Chartes de 1814 et de 1830, Fayard, Paris, 1994, pp. 83, 194. Cheryl B. Welch, Liberty and utility. The French Idéologues and the Transformation of Liberalism, Columbia University Press, Nueva York, 1984. Paul Bénichou, Le sacre de l'écrivain, 1750-1830. Essai sur l'avènement d'un pouvoir spirituel laïque dans la France Moderne, Corti, París, 1973 (trad. de Aurelio Garzón del Camino, La coronación del escritor. Ensayo sobre el advenimiento de un poder espiritual laico en la Francia moderna, Fondo de Cultura Económica, México, 1981, p. 236). María Luisa Sánchez-Mejía, Benjamin Constant y la construcción del liberalismo posrevolucionario, Alianza, Madrid, 1992. Luigi Lacchè, "Constitución, monarquía, parlamento: Francia y Bélgica ante los problemas y modelos del constitucionalismo europeo (1814-1848)", Fundamentos: Cuadernos monográficos de Teoría del Estado, Derecho Público e Historia Constitucional, $\mathrm{n}^{\circ}$. 2, 2000, pp. 467-543. Luigi Lacchè, "Las Cartas otorgadas: la teoría de L'Octroi y las experiencias constitucionales en la Europa post-revolucionaria", Fundamentos: Cuadernos monográficos de Teoría del Estado, Derecho Público e Historia Constitucional, $\mathrm{n}^{\circ}$. 6, 2010, pp. 269-305. Alain Laquièze, Les origines du régime parlementaire en France (1814-1848), Presses Universitaires de France, París, 2002, pp. 37 y ss. Manuel Carbajosa Aguilera, "Los caminos posibles del liberalismo posrevolucionario", Revista Internacional de Pensamiento Politico, nº. 13, 2018, pp. 195-220.

2 Vid. p. ej. Carta de Friedrich Gentz al conde de Nesselrode, Paris, 22 de noviembre de 1815, en Comte Anatole de Nesselrode, Lettres et papiers du Chancelier Comte de Nesselrode, 1760-1850, Lahure, París, vol. V, 1907, p. 237 cit. en Josep Fontana, De en medio del tiempo. La segunda restauración española, 1823-1834, Crítica, Barcelona, 2006, p. 12.

3 Vid. Antonio Rivera García, Reacción y Revolución en la España liberal, Biblioteca Nueva, Madrid, 2006, p. 21. Cfr. Sánchez-Mejia, Benjamin Constant y la construcción del liberalismo posrevolucionario, op. cit., pp. 133 y ss. 
este titánico empeño de búsqueda de equilibrios entre el Antiguo Régimen y la Revolución y de recomposición de unas nuevas jerarquías sociales acordes con el espíritu de los tiempos, se desarrolla un conjunto de reflexiones en torno a los limites de la libertad que en el caso concreto de François Pierre Guillaume Guizot (1787-1874) podemos calificar de teoría de la libertad limitada, haciéndonos justo eco de las palabras de Paul Bénichou, quien acierta al subrayar que la doctrina politica de Guizot no es en esencia una doctrina de la libertad, sino más bien "una teoría de los limites de la libertad"4.

\section{TEORÍA DE LA LIBERTAD LIMITADA EN GUIZOT.}

En su obra de referencia Liberalism under Siege: The Political Thought of the French Doctrinaires (2003), Aurelian Craiutu expone unas didácticas pautas para sistematizar la filosofia política de Guizot y por extensión del resto del grupo doctrinario, distinguiendo cinco grandes teorias: teoría del poder, de la publicidad, del gobierno representativo, de la democracia y de la soberania ${ }^{5}$. Aun cuando la teoría de la soberanía de la razón es la clave de bóveda del pensamiento doctrinario, creemos que el análisis de la concepción de la libertad esgrimida por Guizot contribuye a comprenderlo en su totalidad y hondura, una libertad a la que hemos añadido el calificativo de limitada porque está supeditada al orden como premisa para su existencia en sociedad. La sombra del "spectre du jacobinisme" era, sin duda, alargada.

De entre sus obras, es en su Histoire des origenes du gouvernement représentatif en Europe (1851) donde Guizot condensa de manera más didáctica su visión de la libertad al reunir un conjunto de lecciones que fueron impartidas en la Sorbona durante los años 1820 a $1822^{6}$. Esto, unido al hecho de que contamos con la primera traducción al español de esta obra desde 20097 , nos ha llevado a concentrar en ella nuestro marco referencial.

Guizot considera que tanto la monarquía absoluta como la pura teocracia resultan ser modelos politicos enfrentados a la libertad, pero también, vista la

\footnotetext{
4 Vid. Paul Bénichou, Le temps des prophètes. Doctrines de l'âge romantique, Gallimard, Paris, 1977 (trad. de Aurelio Garzón del Camino, El tiempo de los profetas. Doctrinas de la época romántica, Fondo de Cultura Económica, México, 1984, p. 38).

5 Vid. Aurelian Craiutu, Liberalism under Siege: The Political Thought of the French Doctrinaires, Lexington Books, Lanham, Maryland, 2003 (trad. al francés de Isabelle Hausser, Le Centre introuvable. La pensée politique des doctrinaires sous la Restauration, Plon, París, 2006, pp. 21 y ss.).

6 Vid. François Guizot, Histoire des origines du gouvernement représentatif en Europe, 1820, Meline, Cans et Cie., Bruselas, 2 vols., 1851 (trad. en un volumen de Marceliano Acevedo Fernández, Historia de los origenes del gobierno representativo en Europa, KRK ediciones, Oviedo, 2009).

7 Vid. Ramón Punset, "Guizot y la legitimidad del poder" en Guizot, Historia de los origenes del gobierno representativo en Europa, op. cit., p. 15. También, Ignacio Fernández Sarasola, "Reseña del libro de François Guizot, Historia de los origenes del gobierno representativo en Europa, introducción de Ramón Punset, trad. Marceliano Acevedo Fernández, KRK ediciones, Oviedo, 2009, 1024 págs.”, Revista de Estudios Políticos, nº. 153, julio-septiembre 2011, p. 273. Joan Josep Adrià i Montolio, "La civilización doctrinaria: Guizot y la historia europea (primera parte)", La Torre del Virrey. Revista de estudios culturales, nº. 16, 2014, pp. 87-110.
} 
experiencia de la Convención jacobina, lo es una democracia no regulada. Esto significa que la dominación absoluta de una idea o de un principio de organización social resulta peligrosa para la libertad política, puesto que contraviene su esencial naturaleza plural ${ }^{8}$. Guizot afirma que en la Historia existe un fin último ligado a la realización sobre la Tierra de los preceptos de la razón, la verdad y la justicia. Entiende que los individuos no son "agents passifs de la Providence", sino que han sido agraciados por Dios para desarrollar su inteligencia y la libertad del conjunto de la nación, lo que ha llevado a Craiutu a hablar de providencialismo9. Desde esta óptica, el marco de desarrollo de la libertad, predeterminada por la existencia de un orden que inspira sus bases y sus limites, su fundamento y sus fronteras, resultará profundamente estrecho.

Para despejar la incógnita de la libertad posible, Guizot se muestra fiel al ineludible zeitgeist que caracteriza a aquella época en la que el hombre contemporáneo, despojado de todo referente, ya antiguo, ya moderno, se afana en recoger los restos de la ruina y en elaborar sintesis capaces de reconstruir una sociedad devastada por la lucha entre el privilegio y la libertad. En este sentido, Guizot va a confrontar dialécticamente a la libertad natural con la libertad en sociedad para descartar en primera instancia a la voluntad individual como fundamento de la libertad. En un segundo momento, va a enfrentar, dentro de la libertad en sociedad, a la razón subjetiva con la razón objetiva, trascendente y humanamente inaccesible en su plenitud, desechando en este estadio a la razón subjetiva. El resultado final es que, incómodo como pocos respecto al potencial subversivo que presupone en la esencia de la libertad, en opinión de Guizot la sociedad no se caracteriza por la autonomía del individuo, sino por su obediencia a unos valores de verdad, razón y justicia supra-individuales. La única libertad posible será, por tanto, aquella que queda en manos de una élite de capaces encargados no de ejercer un derecho, sino de desarrollar una función moral consistente en desvelar progresivamente el camino hacia esos valores absolutos. Como señala Bénichou, "las ideas son también afectos"10, y Guizot, más que afecto, tenía temor a aquella libertad de los modernos, de tal modo que en su obsesión por domesticarla terminó anulándola ${ }^{11}$.

\subsection{La libertad natural y la libertad en sociedad: el ataque a la voluntad individual.} hombre:

En opinión de Guizot hay dos maneras de comprender la libertad del

\footnotetext{
8 Vid. Craiutu, Le Centre introuvable, op. cit., pp. 69-72.

9 Vid. Craiutu, Le Centre introuvable, op. cit., p. 73.

10 Bénichou, El tiempo de los profetas, op. cit., p. 110.

${ }^{11}$ Sánchez-Mejía, Benjamin Constant y la construcción del liberalismo posrevolucionario, op. cit., pp. 170 y ss. Pierre Rosanvallon, "Les Doctrinaires sont-ils des libéraux?", en Darío Roldán (ed.), Guizot, les Doctrinaires et la Presse (1820-1830), Fondation Guizot-Val Richer, Paris, 1994, pp. 133-139. Vid. Craiutu, Le Centre introuvable, op. cit., pp. 88 y ss. Lucien Jaume, L'individu effacé ou le paradoxe du libéralisme français, Fayard, Paris, 1997, passim.
} 
" $1^{\circ}$ como la independencia del individuo que no tiene otra ley que su propia voluntad; $2^{\circ}$ como la independencia de todo individuo de cualquier otra voluntad individual contraria a la razón y a la justicia"12.

La primera, de filiación rousseauniana, es una libertad natural, donde impera la voluntad individual, resultando "bárbara y antisocial" porque "la sociedad no puede existir más que por la obediencia de los individuos a una regla común"13. Para un Guizot que teme a la autonomía del individuo, la vida en sociedad solo es posible, solo es gobernable, sobre la base de la obediencia, no de la libertad individual, que tiende, a su juicio, a la disgregación social. De este modo, la libertad natural es anti-social porque supone la soberanía de uno mismo y por tanto "el derecho a no obedecer nada más que a la propia voluntad"14. Este concepto de libertad impide, además, su representación:

“¿Quién le dice a usted que su representante tendrá siempre y en toda ocasión la misma voluntad que usted? Con toda seguridad, no sucederá nada de eso. Lejos, pues, de que él le represente, ha enajenado en él su voluntad, su soberanía, su libertad. Se ha procurado usted no un representante, sino un amo"15.

Consecuentemente, la libertad natural es para Guizot destructora de todo gobierno y de toda sociedad, porque precipita al individuo a un aislamiento absoluto, dado que todo propósito de contraer una obligación o de someterse a la ley conllevaría la renuncia al imperio de la voluntad individual. La idea de Rousseau según la cual "nadie está obligado a obedecer las leyes que él no ha aprobado" es incompatible con cualquier modalidad de poder ${ }^{16}$, por lo que “(...) este pretendido principio es incapaz de crear legítimamente el gobierno de la sociedad"17.

\subsection{La libertad en sociedad: el imperio de la razón trascendente al servicio de unos pocos. El ataque a la razón subjetiva.}

Guizot entiende que las leyes morales proceden de una esfera superior a la de la libertad individual. Es decir, que “(...) por encima de la voluntad del individuo planea una cierta ley, llamada alternativamente razón, moral o verdad, y a la que nadie puede sustraer su conducta sin hacer de su libertad un empleo

12 Guizot, Historia de los origenes del gobierno representativo en Europa, op. cit., p. 322.

13 Ibid.

14 Guizot, Historia de los origenes del gobierno representativo en Europa, op. cit., pp. 649-653.

15 Ibid.

16 Guizot, Historia de los orígenes del gobierno representativo en Europa, op. cit., p. 654. Vid. Darío Roldán, "Guizot, Constant y la crítica liberal a la soberanía popular”, Libertas, n. 30, 1999, pp. 215 y ss.

17 Guizot, Historia de los origenes del gobierno representativo en Europa, op. cit., pp. 657, 661. Vid. también François Guizot, "Philosophie politique: De la souveraineté" en François Guizot, Histoire de la civilisation en Europe, présenté par Pierre Rosanvallon, Hachette, París, 1985, pp. 363 y ss. Vid. Aurelian Craiutu, "Introduction" en François Guizot, History of the Origins of Representative Government in Europe, Liberty Fund, Indianápolis, 2002, p. XV. 
absurdo o culpable"18. El grupo doctrinario coincide en la idea de que no es en la libertad individual, sino "en la libertad pública donde hay que extraer la energía vital que todo gobierno necesita tomar de la sociedad; es a la razón pública a la que hay que demandarle la protección primera del orden y de las leyes"19. Por tanto, a juicio de estos autores, la única libertad posible no viene ni de la tradición, ni de la voluntad, ni del hábito, ni de la fuerza, sino que solo es concebible desde una dimensión pública en tanto imperfecto reflejo de una razón trascendente. Esto supone que:

“(...) el individuo considerado en sí mismo no dispone de sí arbitrariamente y según su sola voluntad. No es su voluntad la que crea e impone leyes obligatorias. Él las recibe de más arriba; le vienen de una esfera superior a la de la libertad, de una esfera donde la libertad no existe, donde el debate surge no entre lo que se quiere y lo que no se quiere, sino entre lo que es verdadero o falso, justo o injusto, conforme o contrario a la razón”20.

Desde esta concepción Guizot puede afirmar: "Es preciso que el hombre defienda su libertad contra los poderes ilegitimos, y el poder legitimo contra su propia libertad"21. Esta prelación resulta muy ilustrativa del pensamiento político guizotiano. Su anti-individualismo descansa en la convicción de que no existe la libertad en esa esfera porque en ella reside la infalibilidad divina. Aquí se asienta el fundamento de la limitación de la libertad para Guizot. Él considera que "cuando se ha querido fundar la soberanía de los reyes, se ha dicho que los reyes son la imagen de Dios sobre la Tierra. Cuando se ha querido fundar la soberanía del pueblo, se ha dicho que la voz del pueblo es la voz de Dios. Entonces, solo Dios es soberano. Dios es soberano porque es infalible". Como solo la infalibilidad puede reclamar obediencia, cualidad inaccesible en cuanto atributo divino, la soberania de derecho resulta inalcanzable por encontrarse el hombre prisionero de la falibilidad y de la debilidad. La única soberanía humanamente posible es la soberanía de hecho, fundamentada en la permanente búsqueda del ideal de la soberanía de derecho, búsqueda para la que se requiere conocimiento, razón. Por

18 Guizot, Historia de los origenes del gobierno representativo en Europa, op. cit., p. 661. Vid. Pierre Rosanvallon, Le moment Guizot, Gallimard, París, 1985 (trad. de Hernán M. Díaz, El momento Guizot. El liberalismo doctrinario entre la Restauración y la Revolución de 1848, Biblos, Buenos Aires, 2015, p. 73).

19 Archives philosophiques, politiques et littéraires, Fournier, París, t. II, 1818, p. 261 (traducido en Rosanvallon, El momento Guizot, op. cit., p. 55).

20 Guizot, Historia de los origenes del gobierno representativo en Europa, op. cit., pp. $662-663$ (el resaltado es nuestro).

21 Vid. Guizot, Philosophie politique : De la souveraineté, op. cit., p. 372 (trad. Darío Roldán, "Guizot, Constant y la critica liberal a la soberanía popular", op. cit., p. 221, resaltado en el original). Cfr. Benjamin Constant, De la liberté des anciens comparée à celle des modernes, discurso pronunciado en el Ateneo Real de París en 1819, reproducido en Édouard Laboulaye (ed.), Benjamin Constant, Cours de politique constitutionnelle ou collection des ouvrages publiés sur le gouvernement représentatif, Librairie de Guillaumin et Cie., Paris, t. II, 1861, pp. 537-560 (seguimos la trad. de María Luisa Sánchez-Mejía, "De la libertad de los antiguos comparada con la de los modernos", en María Luisa Sánchez-Mejía (ed.), Benjamin Constant, Escritos politicos, estudio preliminar, traducción y notas de María Luisa Sánchez-Mejía, Centro de Estudios Constitucionales, Madrid, 1989, pp. 257-285). Cfr. Jaume, L’individu effacé ou le paradoxe du libéralisme français, op. cit., pp. 25-117; 119-169. 
tanto, para Guizot el gobierno representativo está basado en la selección del más alto grado de razón que la sociedad puede reunir en cada momento ${ }^{22}$.

Desde este iusnaturalismo racio-trascendente se cimenta la teoría doctrinaria de la soberanía de la razón, en la que “(...) la soberanía no abandona la razón para atribuirse a la voluntad"23. Según Rosanvallon, Guizot considera que "si la razón es soberana, los hombres no podrian inventar las leyes; se trata solamente de descubrirlas"24, por lo que tanto la voluntad como la razón individual están condicionadas por leyes supra-individuales:

“(...) el hombre no tiene en sí mismo y en virtud de su voluntad un poder absoluto. Como ser racional y moral, está sujeto a las leyes que él no hace y que le obligan por derecho, aunque como ser libre tenga el poder de negarles no su asentimiento sino su obediencia" 25.

Guizot llega al convencimiento, al estudiar el fundamento de la libertad natural, de que la voluntad individual no genera el derecho, ni confiere legitimidad al poder, porque por encima de ella se encuentran la verdad, la razón y la justicia ${ }^{26}$. Pero va más allá: desde la libertad en sociedad tampoco la razón subjetiva puede generar por sí misma derecho, porque por encima de ella existe una razón objetiva definitoria de la sociedad. Como señala en este sentido Raquel Sánchez García, “(...) la libertad no sería el ejercicio de la voluntad individual (con los limites que marcan las esferas individuales de los demás), sino la capacidad de realizar en la práctica la norma objetiva y, por tanto, la moral que lleva implícita. Es decir, la adecuación de la razón subjetiva a la razón objetiva"27. De este modo, al considerar a la razón objetiva una regla moral, superior al hombre, no hay lugar a la libertad, sino a un camino de perfección donde solo hay lugar a la obediencia. Esto nos lleva a inferir que cuando Guizot se refiere a la soberanía de la razón no está apelando a la razón inmanente del racionalismo ilustrado, sino a la existencia de un orden trascendente e inaccesible a la mayoría de la población por falta de conocimientos derivada de su incapacidad patrimonial. Su apelación a la razón es una estrategia de selección social bajo el pretexto de servir de instrumento para acceder al conocimiento, siempre incompleto, de ese orden superior. Resulta paradójico que los defensores de la soberanía de la razón

22 Vid. Guizot, Philosophie politique : De la souveraineté, op. cit., pp. 325 y ss., cit. y trad. en Darío Roldán, "Guizot, Constant y la crítica liberal a la soberanía popular", op. cit., p. 219. Aurelian Craiutu, "The Battle for Legitimacy: Guizot and Constant on Sovereignty", Historical Reflections/Réflexions Historiques, vol. 28, $\mathrm{n}^{\circ}$. 3, 2002, pp. 471-491.

23 Guizot, Historia de los origenes del gobierno representativo en Europa, op. cit., p. 663. Craiutu, Le Centre introuvable, op. cit., pp. 122 y ss. Vid. Fernández Sarasola, "Reseña del libro de François Guizot, Historia de los origenes del gobierno representativo en Europa, introducción de Ramón Punset, trad. Marceliano Acevedo Fernández, KRK ediciones, Oviedo, 2009, 1024 págs.”, op. cit., pp. 279-280. Rosanvallon, El momento Guizot, op. cit., p. 57. Constant, en su defensa de las libertades individuales, negará ese deber ser trascendente, cfr. Sánchez-Mejía, Benjamin Constant y la construcción del liberalismo posrevolucionario, op. cit., pp. 156 y ss.

24 Rosanvallon, El momento Guizot, op. cit., p. 76.

25 Guizot, Historia de los orígenes del gobierno representativo en Europa, op. cit., p. 663.

26 Vid. Rosanvallon, El momento Guizot, op. cit., p. 73.

27 Raquel Sánchez García, "El liberalismo posrevolucionario", en Pedro Carlos González Cuevas, Ana Martínez Arancón (coords.), Ideas y formas politicas: del triunfo del absolutismo a la posmodernidad, UNED, Madrid, $7^{\text {a }}$ reimp., 2019 (1 ${ }^{\mathrm{a}}$ ed., 2010), p. 240. 
reduzcan precisamente a la razón a exigencia previa para ejercer una función moral impregnada de intuición. En su obsesión por constituir una nueva jerarquización social, el providencialismo guizotiano que apela a la intuición de la élite de los creyentes no solo pretende cerrar el camino de la revolución, sino que en muchos aspectos está facilitando el terreno para que germine, en lontananza y como efecto colateral, el irracionalismo político ${ }^{28}$.

Según Diez del Corral, Guizot considera que "la vida del hombre se mueve dentro de un mundo ordenado, superior a las determinaciones de la voluntad; la libertad no consiste sino en el derecho que a cada uno corresponde para hacerse respetar en el cumplimiento de su destino moral"29. De aquí parte la teoría doctrinaria del poder, donde resalta la relación sociedad-obediencia:

“(...) el derecho al poder se deriva siempre de la razón, nunca de la voluntad. Nadie tiene derecho a dictar la ley porque él lo quiera; nadie tiene derecho a rechazarla porque no la quiera; y la legitimidad del poder reside en la conformidad de sus leyes con la razón eterna, no en la voluntad del hombre que ejerce el poder ni en la del hombre sobre el que se ejerce"30.

Siguiendo a Sánchez García, esto significa que "si el gobierno representativo ha sido capaz de fijar la ley objetiva, ha de conducir a los hombres a su cumplimiento, velando para que éstos no estén sometidos a más ley que la emanada de la razón objetiva, que será la plasmación jurídica de la justicia (el derecho)"31. La preeminencia de la razón trascendente, superior e inalcanzable, permite considerar a Guizot que la legitimidad del poder depende de su conformidad a la razón objetiva y supra-individual: "(...) el poder solo es legítimo en cuanto que es conforme a la razón"32. Esta reflexión lleva a Guizot a definir a la libertad:

"La libertad, considerando al hombre en sí mismo, es el poder de conformar su voluntad a la razón. Por eso es por lo que es sagrada; del mismo modo el derecho a la libertad, en las relaciones del hombre con el hombre, se deriva del derecho a no obedecer nada más que a la razón"33.

Partiendo de la diferencia entre "la libertad moral o de derecho y la libertad natural o de hecho, entre la libertad social y la independencia individual", Guizot formula su teoria de la libertad:

"El hombre es sublime en cuanto ser racional y capaz de reconocer la verdad; ahí reside la divinidad de su naturaleza; su libertad no es otra cosa que el poder de obedecer a la verdad que él

28 Vid. Vid. Luis Diez del Corral, El liberalismo doctrinario, Centro de Estudios Constitucionales, Madrid, 4ª ed., 1984, p. 233. Rosanvallon, El momento Guizot, op. cit., pp. 72-73. Rosanvallon, "Présentation" a François Guizot, Philosophie politique: De la souveraineté, op. cit., p. 310. Michael Drolet, "Carrying the banner of the bourgeoisie: Democracy, Self and the Philosophical Foundations to François Guizot's historical and political thought", History of Political Thought, vol. XXXII, $\mathrm{n}^{\circ} .4$, winter 2011, pp. 647 y ss.; 655-661.

29 Vid. Diez del Corral, El liberalismo doctrinario, op. cit. p. 234.

30 Guizot, Historia de los orígenes del gobierno representativo en Europa, op. cit., p. 668. Vid. Craiutu, Le Centre introuvable, op. cit., pp. 151 y ss.

31 Sánchez Garcia, “E1 liberalismo posrevolucionario”, op. cit., p. 240.

32 Guizot, Historia de los origenes del gobierno representativo en Europa, op. cit., p. 673.

33 Ibíd. 
puede reconocer y a la que puede adecuar sus actos. Por esta razón la libertad es muy respetable, pero solo lo es por este motivo" 34 .

Hernán M. Díaz, en la traducción de El momento Guizot de Rosanvallon, enfatiza el fragmento: "la libertad no es en el hombre sino la potencia de obedecer a la verdad que pueda reconocer, y de conformar a ella sus actos"35. Ahí está condensada la idea esencial de Guizot sobre la libertad: la libertad es potencia de obedecer la verdad suprema, la esfera de libertad depende de la capacidad o potencia de obedecer a esa verdad supra-individual, acto revestido de moralidad y ejercido por una élite, frente a los demás que, incapaces para desarrollar tan privilegiada función, están condenados al ostracismo social. Al ligar esa capacidad con la propiedad, el resultado de la relación permite a estos pensadores desarrollar una teoria del desprecio social al servicio de la plutocracia posrevolucionaria, so pretexto de consolidar una nueva aristocracia social que garantice la gobernabilidad. Como escribe Rosanvallon, “(...) la clave de bóveda de la teoría doctrinaria del poder social descansa sobre la noción de capacidades. La división social entre los capaces y la multitud permite en última instancia hacer del poder social un poder razonable, a la vez dentro y fuera de la sociedad. Esta distinción sociológica da a la filosofia política doctrinaria su coherencia"36.

Guizot considera que "la conciencia de la justicia y del derecho, es decir, de una regla independiente de las voluntades humanas" desvela que “(...) toda soberanía de derecho atribuida a algún hombre - uno, varios o todos- es una mentira y una iniquidad"37. Esto le lleva a razonar que:

“(...) el hombre que se siente libre y capaz de acción entrevé siempre una ley natural de su acción. Reconoce algo que no es su voluntad y que debe regir a su voluntad. Se siente racional y moralmente obligado a algo; ve o siente que hay algo que debe hacer o no hacer. Este algo es la ley superior al hombre y hecha para él, la ley divina" 38 .

\section{Sobre esta base asienta su teoría del gobierno:}

"He ahí, por tanto, la verdadera ley de la sociedad, hemos encontrado la ley del gobierno. Es la misma ley que obliga a los individuos. Y del mismo modo que para el individuo, la verdadera ley es con frecuencia oscura, y como el individuo, incluso cuando la conoce bien, no siempre la sigue, otro tanto pasa con el gobierno; (...). Es pues imposible atribuir a un hombre o a varios la soberanía de derecho, pues seria suponer que saben y quieren, en todos los casos, lo que quiere la justicia y la razón. Suposición inadmisible en razón de la imperfección radical de nuestra naturaleza"39.

\section{UNA LIBERTAD AL SERVICIO DE LA GOBERNABILIDAD.}

34 Guizot, Historia de los origenes del gobierno representativo en Europa, op. cit., pp. 324-325.

35 Vid. Rosanvallon, El momento Guizot, op. cit., p. 74 (el subrayado es nuestro).

36 Rosanvallon, El momento Guizot, op. cit., pp. 59-60. Bénichou, El tiempo de los profetas, op. cit., pp. 38-39. Cfr. Sánchez-Mejia, Benjamin Constant y la construcción del liberalismo posrevolucionario, op. cit., pp. 167, 212.

37 Guizot, Historia de los origenes del gobierno representativo en Europa, op. cit., p. 147.

38 Guizot, Historia de los origenes del gobierno representativo en Europa, op. cit., pp. 147-148.

39 Guizot, Historia de los origenes del gobierno representativo en Europa, op. cit., pp. 148-149. Vid. Craiutu, Le Centre introuvable, op. cit., pp. 109, 159 y ss., 180 y ss. 
Guizot clasifica a los gobiernos en dos clases, no por su forma, sino por su esencia:

"Unos, que atribuyen exclusivamente la soberanía de derecho a individuos, uno, varios o todos, fundan el despotismo como principio. (...) Otros están fundados en la verdad de que la soberanía de derecho no pertenece a nadie porque el conocimiento pleno y continuo, la aplicación exacta e imperturbable de la justicia y de la razón no pertenecen a nuestra naturaleza imperfecta" 40 .

Para Guizot, el gobierno representativo reposa sobre esta última verdad porque "no atribuye la soberanía de derecho a nadie" ${ }^{41}$. Sobre esta reflexión se constituye su teoría del poder:

"Todo poder es un poder de hecho que, para ser poder de derecho, debe actuar según la razón, la justicia, la verdad, única fuente de derecho. Ningún hombre ni ninguna reunión de hombres conocen y practican plenamente la razón, la justicia y la verdad; pero tienen la facultad de descubrirlas y pueden ser conducidos a adecuar cada vez más su conducta a ellas" ${ }^{42}$.

Reconoce que únicamente en una sociedad libremente organizada el hombre puede ser libre 43 . Como el resto de pensadores doctrinarios, Guizot considera que no existe el individuo aislado, sino en sociedad, y por tanto los grandes principios, los grandes valores, están conectados, se equilibran para formar la totalidad social, la convivencia. El ejercicio de la libertad individual depende del marco jurídico y moral que regula las condiciones de la libertad posible ${ }^{44}$. Como señala Sánchez García, para Guizot “(...) no puede existir más libertad que la libertad que se halla en la sociedad. La libertad no es algo que lleva aparejado el hombre por naturaleza, sino que solo se concibe en sociedad. E1 derecho solo existe en sociedad y únicamente el derecho es garantía de libertad"45. Frente a Guizot, Benjamin Constant considera que lo esencial, en cuanto verdadera libertad moderna, es la libertad individual, mientras que la libertad politica es su indispensable garantía, advirtiendo que "pedir a los pueblos de nuestros dias que sacrifiquen, como los de antes, la totalidad de su libertad individual a la libertad política, es el medio más seguro para apartarles de la primera y, cuando eso se haya logrado, no se tardará en arrancarles la segunda"46. Sin embargo Guizot entiende que los derechos individuales no

40 Guizot, Historia de los origenes del gobierno representativo en Europa, op. cit., p. 150.

41 Guizot, Historia de los origenes del gobierno representativo en Europa, op. cit., p. 151.

42 Guizot, Historia de los origenes del gobierno representativo en Europa, op. cit., pp. 155-156. Vid. Craiutu, Le Centre introuvable, op. cit., pp. 154 y ss.

43 Vid. Diez del Corral, El liberalismo doctrinario, op. cit., p. 263.

44 Vid. François Guizot, Des moyens de gouvernement et d'opposition dans l'état actuel de la France, Ladvocat, París, 1821, p. 2. El éxito de la obra y el consiguiente recelo del Gobierno, desemboca en la suspensión universitaria de Guizot y Cousin en 1822, vid. Alberto Clerici, "Contro l'uguaglianza, contro il privilegio. Il giovane Guizot e i suoi critici (1820-1821)", en Giovanni Ruocco y Luca Scuccimarra (coord.), Il governo del popolo. 2.- Dalla Restaurazione alla guerra franco-prussiana, Viella, Roma, 2012, p. 62.

45 Sánchez García, “E1 liberalismo posrevolucionario”, op. cit., p. 240.

46 Cfr. Constant, "De la libertad de los antiguos comparada con la de los modernos", en Sánchez-Mejía (ed.), Benjamin Constant, Escritos politicos, op. cit., pp. 278 y ss. 
pueden constituirse en barreras defensivas entre los individuos, sino en "factores activos de sociabilidad" 47 .

La libertad, además, cumple una función legitimadora del poder de hecho, pues "la libertad sólo es garantía en cuanto que el poder está obligado a probar su legitimidad", esto es, "su conformidad con la razón eterna"48. Sobre este planteamiento descansa la teoría doctrinaria de la representación:

"Lejos, pues, de que la representación se fundamente sobre el derecho inherente de todas las voluntades a participar en el poder, reposa por el contrario sobre el principio de que ninguna voluntad tiene por sí misma derecho al poder y que cualquiera que ejerce el poder o pretende ejercerlo está obligado a demostrar que lo ejerce o lo ejercerá no según su voluntad, sino según la razón" 49 .

\section{Para Guizot el objetivo del gobierno representativo es doble:}

“ $1^{\circ}$. buscar y descubrir la verdadera ley que debe decidir en todas las circunstancias que surgen de las relaciones sociales y someter a esta ley a todas las voluntades individuales que le son contrarias; $2^{\circ}$. impedir que los individuos estén sometidos a otras leyes distintas a ésta, es decir, a la voluntad arbitraria de otros individuos más fuertes"50.

Frente al imperio de la voluntad, asimilado al de la fuerza, el de la razón es para Guizot fruto no de la abstracción, sino de los progresos de la civilización ${ }^{51 .}$ Al reforzar a la razón en detrimento de la voluntad se pretende, entre otros propósitos, eliminar las pasiones de la política en favor del rigor científico de la razón como antídoto al despotismo. El proceso de despersonalización conduce al reforzamiento de los mecanismos institucionales como expresión racional del funcionamiento de la política, rebajada de idealismos y encajonada, como contrapartida, en la mecánica de la gestión. En esta tarea encontramos un detalle importante en materia jurídica, como señala Punset: al atribuir la soberanía al Estado - $-\mathrm{y}$ al considerar a la nación "como un ente moral o de ficción, sujeto unitario y abstracto, que solo existe por y para el Derecho" - está trasladando la cuestión de la soberanía desde lo político - en cuanto espacio plural, conflictivo e indeterminado - hasta lo jurídico —en cuanto espacio plural, científico y determinado-, alejándola de este modo del dominio de las pasiones, contexto de suyo inestable, para situarla en el de la estabilidad de la gestión mecánica del Derecho, fiel a su cientificismo politico ${ }^{52}$. Como Rosanvallon subraya, la

47 Vid. Díez del Corral, El liberalismo doctrinario, op. cit., pp. 263-266. Rosanvallon, "Présentation" a François Guizot, Philosophie politique: De la souveraineté, op. cit., pp. 309 y ss. Vid. Jaume, L'individu effacé ou le paradoxe du libéralisme français, op. cit., pp. 122 y ss. Sánchez García, "El liberalismo posrevolucionario", op. cit., pp. 240-241. François Guizot, De la démocratie en France, Plon-Víctor Masson, París, 1849 (traducción, introducción y notas de Dalmacio Negro Pavón, De la democracia en Francia, Centro de Estudios Constitucionales, Madrid, 1981, p. 133).

48 Guizot, Historia de los orígenes del gobierno representativo en Europa, op. cit., pp. 673-674.

49 Guizot, Historia de los orígenes del gobierno representativo en Europa, op. cit., p. 674. Vid. Craiutu, Le Centre introuvable, op. cit., pp. 108 y ss., 208 y ss.

50 Guizot, Historia de los origenes del gobierno representativo en Europa, op. cit., p. 323.

51 Vid. Guizot, Historia de los orígenes del gobierno representativo en Europa, op. cit., p. 324.

52 Vid. Punset, "Guizot y la legitimidad del poder", op. cit., pp. 17-18, 28-30. Luigi Lacchè, La Libertà che guida il Popolo. Le Tre Gloriose Giornate del luglio 1830 e le "Chartes" nel costituzionalismo francese, Il Mulino, Bolonia, 2002, pp. 87 y ss.; 155 y ss. 
Restauración se afana en “(...) sacar la política del dominio de las pasiones para integrarla en la edad de la razón"53. Igualmente para Punset:

"Había que sustituir la aleatoriedad de la voluntad por la regularidad de un orden científico. De ahí la crítica generalizada del dogma de la soberanía del pueblo, acusado de haber propiciado los excesos revolucionarios; de ahí también la pretensión de encontrar el camino hacia un gobierno "racional" y una política "científica"" 54 .

\section{LA SEGUNDA LEGITIMIDAD DE LA LIBERTAD LIMITADA: EL GRADO DE CIVILIZACIÓN.}

Hemos visto que la legitimidad moral de la libertad en sociedad procede para Guizot de su aspiración a reflejar los valores absolutos y divinos de la verdad, la razón y la justicia. Según el "iusnaturalismo tradicional, no secularizado" de Guizot, detrás de la ley, por encima de la ley está la razón, la verdad y la justicia como fuente de ley. Destruida la autoridad legal de Dios por el proceso de secularización de la modernidad, Guizot lo recupera en forma de razón trascendente revelada a los más capaces, legitimadora de la soberanía de la nueva era: la soberanía de la razón ${ }^{55}$. En este proceso de readaptación de las jerarquias sociales ${ }^{56}$, y frente a la idea revolucionaria de la legitimidad desde abajo que supone la soberanía del pueblo, Guizot enlaza su pre-grociana interpretación del Derecho natural — pretendiendo la legitimidad desde arribacon la legitimidad horizontal de la Historia y del concepto de civilización.

Guizot reconoce que en el comienzo de las sociedades "la libertad que quieren y defienden casi todos los hombres es la libertad natural, la libertad de hacer solo la propia voluntad". Este estado lo liga a la "imperfección del desarrollo moral de cada individuo y a la imperfección del propio desarrollo de los poderes sociales", confluencia de obstáculos que les impide a estas sociedades descubrir la verdadera ley. Por este motivo, "la sociedad no puede subsistir si la libertad natural, es decir, la independencia individual, subsiste en toda la extensión de su deseo". En esta situación, en la que "la sociedad no sabe todavía gobernar según la ley moral ni respetar la libertad moral, es la fuerza la que se apodera del gobierno"57. En ese contexto se desarrolla el despotismo. El propio Guizot reconoce la diferencia entre el despotismo de uno solo y el de la "multitud brutal ejercido sobre alguna inteligencia individual", decantándose en última instancia,

53 Rosanvallon, El momento Guizot, op. cit., p. 18.

54 Punset, “Guizot y la legitimidad del poder", op. cit., pp. 17-18.

55 Vid. Punset, "Guizot y la legitimidad del poder", op. cit., pp. 17 y ss. Rosanvallon, El momento Guizot, op. cit., pp. 72 y ss., 84. Fernández Sarasola, "Reseña del libro de François Guizot, Historia de los orígenes del gobierno representativo en Europa, introducción de Ramón Punset, trad. Marceliano Acevedo Fernández, KRK ediciones, Oviedo, 2009, 1024 págs.”, op. cit., pp. 282 y ss. Guizot, Historia de los origenes del gobierno representativo en Europa, op. cit., pp. 158-159.

56 Vid. Rosanvallon, El momento Guizot, op. cit., pp. 85 y ss. Pierre Rosanvallon, Le modèle politique français. La société civile contre le jacobinisme de 1789 à nous jours, Éditions du Seuil, París, 2004 (trad. de Víctor A. Goldstein, El modelo politico francés: la sociedad civil contra el jacobinismo, de 1789 a nuestros dias, Siglo XXI Editores, Buenos Aires, 2007, pp. 169 y ss.).

57 Vid. Guizot, Historia de los origenes del gobierno representativo en Europa, op. cit., p. 325. 
como todos los doctrinarios, por el primero, al que le reconoce el carácter de superioridad aun cuando termine por corromperse ${ }^{58}$.

Guizot entiende que la civilización se ha desarrollado haciendo irrenunciables los nuevos conceptos que han irrumpido desde 1789, conceptos que, purgados "de tout alliage anarchique"59, han de compatibilizarse con una Historia coadyuvadora en el proceso de legitimación del sistema representativo ${ }^{60}$. Guizot considera que el gobierno representativo no es fruto de la abstracción teórica, sino de los progresos de la civilización ${ }^{61}$. Advierte de la preparación que requiere el ejercicio de la libertad:

“(...) si estamos llamados a poseer y a conservar unas instituciones libres, ellas nos exigen, desde la misma juventud, una preparación fuerte, unos hábitos laboriosos y perseverantes. (...) Sólo los estudios rigurosos preparan para unos destinos importantes. La libertad no es un bien que se adquiera o que se defienda como un juego. (...) Ese fue el error del siglo pasado"62.

Al considerar que la ignorancia convierte al pueblo en un instrumento a disposición de los facciosos ${ }^{63}$, escribe:

"Las leyes y las libertades públicas fueron defendidas solo por hombres así formados. Ellos se resistieron, según las necesidades de cada época, al desorden y a la opresión. Ellos extrajeron de la seriedad de sus pensamientos y de su vida, el sentimiento de su propia dignidad y de ese sentimiento el de la dignidad humana"64.

58 Vid. Guizot, Historia de los origenes del gobierno representativo en Europa, op. cit., pp. 326327. Rivera García, Reacción y Revolución en la España liberal, op. cit., pp. 21 y ss. Es el caso, p. ej. del Discurso sobre la dictadura (1849) de Juan Donoso Cortés, en Diario de las Sesiones de Cortes. Congreso de los Diputados, $\mathrm{n}^{\circ}$. 13, 4 enero 1849, p. 172.

59 Vid. François Guizot, “Discours à la Chambre des députés du 14 mars 1838”, en [François Guizot], Histoire parlementaire de France. Recueil complet des discours prononcés dans les Chambres de 1819 à 1848 par M. Guizot, Michel Lévy Frères, París, t. III, 1863, p. 153. Rosanvallon, El momento Guizot., op. cit., p. 221. Craiutu, Le Centre introuvable, op. cit., pp. 115 y ss.

60 Vid. Guizot, Historia de los origenes del gobierno representativo en Europa, op. cit., pp. 47; 522-524.

61 Vid. Guizot, Historia de los orígenes del gobierno representativo en Europa, op. cit., p. 61. En España, Alberto Lista, entre otros, comparte esta interpretación, vid., p. ej., Manuel Carbajosa Aguilera, "Alberto Lista y el origen del gobierno representativo", Revista Internacional de Pensamiento Político, nº. 11, 2016, pp. 191-211.

62 Guizot, Historia de los origenes del gobierno representativo en Europa, op. cit., pp. 74-75.

63 Vid. François Guizot, Essai sur l'histoire et sur l'état actuel de l'instruction publique en France, Maradan, París, 1816, p. 5. Vid. también Pedro L. López Herraiz, Formar al hombre de Estado. Génesis y desarrollo de la École libre des sciences politiques (1871-1900), Dykinson, Madrid, 2019.

64 Guizot, Historia de los origenes del gobierno representativo en Europa, op. cit., p. 76. Vid, p. ej. el paralelismo en este tema con Lista: Alberto Lista, "Continúa el discurso sobre la reforma de las costumbres", El Espectador Sevillano, n. 26, 27 de octubre de 1809, p. 103; "Continúa el discurso sobre la reforma de las costumbres", El Espectador Sevillano, nº. 27, 28 de octubre de 1809, pp. 105-106; afirmando que "No puede haber sociedad civil sin moral; no puede haber moral sin religión": Alberto Lista, "Prospecto", Gaceta de Bayona, 15 de septiembre de 1828. Vid. también Javier Fernández Sebastián, "La recepción en España de la Histoire de la Civilisation de Guizot", en Jean-René Aymes y Javier Fernández Sebastián (ed.), La imagen de Francia en España (1808-1850), Bilbao-París, Servicio editorial Universidad del País Vasco-Presses de la Sorbonne Nouvelle, 1997, pp. 127-149. 
Considera que únicamente desde el conocimiento que otorga la perspectiva de la Historia pueden desenmascararse las irrealidades de la politica, lo que le permite afirmar que tras el espejismo de unos conceptos idealizados la revolución ocultaba a la fuerza:

"Los teóricos de la revolución se equivocaban o mentían cuando alegaban la soberanía del pueblo. En el fondo no era de la soberanía del pueblo de lo que se trataba, aunque todo el mundo hablara de ella y hasta creyera en ella; era de la victoria de una porción del pueblo sobre otra, de un pueblo sobre otro pueblo. Y como la superioridad numérica era inmensa a favor del pueblo nuevo, la soberanía del pueblo se invocaba como doctrina y como fuerza; porque siempre la fuerza, aun siendo superior, precisa de una doctrina: hasta tal punto necesitan los hombres creer y hacer creer que tienen razón"65.

Anotemos, finalmente, un detalle no menor derivado de esta legitimación horizontal. En De la démocratie en France (1849), escribe Guizot: "El hombre no equivale solo a los seres individuales llamados hombres; se trata del género humano, que tiene una vida de conjunto y un destino general y progresivo: carácter distintivo, exclusivo, de la criatura humana en el seno de la creación" 66. Esto supone la afirmación del paradigma de la perfectibilidad civilizatoria frente al de la bondad del salvaje, postulación que conlleva un reflejo político: "Es de ahí de donde derivan y en lo que se fundamentan la familia y el Estado, la propiedad y la herencia, la patria, la historia, la gloria, todos los hechos y todos los sentimientos que constituyen la vida extensa y perpetua de la humanidad"67. En consecuencia, para Guizot, el proceso de civilización requiere de una política conservadora precisamente de la herencia civilizatoria, frente a otras politicas, ya reaccionarias, ya revolucionarias, que al destruir ese legado de los tiempos, precipitan a la sociedad a la barbarie.

La idea de la libertad limitada permitía, por último, legitimar la estrategia política central de los doctrinarios, cuyo discurso, basado en la dialéctica de términos que consideraban antitéticos, les permitía postularse como la única vía politica posible entre los abismos del Antiguo Régimen y de la Revolución. Sin embargo, esta convicción les llevó a recelar de la pluralidad ideológica, del conflicto político institucionalizado, borrando la distinción entre partido y gobierno e intentando reducir la acción política a la racionalidad de la gestión ${ }^{68}$. Esta actitud responde a la estrategia de consolidación de la nueva élite nacida de la Revolución y el Imperio. Recordemos que junto al Código Civil, la Administración imperial fue una de las grandes herencias de aquellos años turbulentos, y la nueva élite sobre la que se sustentaba no estaba dispuesta a devolver a los antiguos privilegiados el status perdido. No se equivocaba Barthélemy cuando escribia: "Notre administration date de l'Empire; notre

65 François Guizot, Du gouvernement de la France depuis la Restauration et du ministère actuel, Ladvocat, París, $2^{a}$ ed., 1820, p. 138, en Bénichou, El tiempo de los profetas, op. cit., pp. $22-23$. Vid. Guizot, Des moyens de gouvernement et d'opposition dans l'état actuel de la France, op. cit., pp. 139 y ss.; 183-185.

66 Guizot, De la democracia en Francia, op. cit., p. 133.

67 Guizot, De la democracia en Francia, op. cit., pp. 133-135.

68 Vid. Rosanvallon, El momento Guizot, op. cit., pp. 42 y ss. Rosanvallon, "Les Doctrinaires sont-ils des libéraux?”, op. cit., pp. 133-139. Bénichou afirmó que ni la posición politica de Guizot, ni su práctica gubernamental estuvieron unidas necesariamente a la lógica del liberalismo, vid. Bénichou, El tiempo de los profetas, op. cit., p. 39. 
politique date de la Restauration"69. Andando el tiempo, esta élite nueva dirigirá sus esfuerzos a desplazar a la nobleza emigrada a lo largo de la Restauración; así lo logrará a partir de 1830, colocando además a un nuevo Rey plegado a sus intereses bajo la hipoteca de la cuasi-legitimidad y cerrando el paso tanto a las nostalgias reaccionarias de unos, como a las ensoñaciones republicanas de otros. A partir de entonces, blindados frente a toda interpretación alternativa de una realidad a la que le habian vuelto la espalda, terminan desembocando en un conservadurismo asfixiante que salta por los aires en 1848 ante el asombro propio, lo que evidenciaba hasta qué punto habian perdido el sentido de la realidad $^{70}$.

\section{CONCLUSIONES.}

El concepto de libertad limitada de Guizot constituye un elemento esencial de su teoría politica porque se irradia sobre el resto de pilares de su pensamiento. La libertad limitada de Guizot es una construcción intelectual destinada a eliminar tanto a la voluntad individual, como a la razón subjetiva, en favor de una interpretación de la sociedad asimilada a la obediencia hacia unos valores supra-individuales. Estamos ante un pensamiento que es representativo de un estilo y una época marcados por los miedos al Terror, y por extensión, a la superioridad numérica del pueblo, que habían traumatizado a las generaciones hasta 1848, año en el que Guizot y su doctrinarismo sucumben ante la realidad de unos hechos que se les habian vuelto incomprensibles ${ }^{71}$.

Es cierto que hay que anotar en su haber el esfuerzo por consolidar un conjunto de instituciones políticas capaces de dotar de viabilidad al gobierno representativo. Su defensa de una instrucción pública que aleje a la ciudadanía de la ignorancia de la que se nutren la demagogia y el fanatismo es otro de sus legados más importantes. Ahora bien, el miedo dominó el espíritu de Guizot y del resto de doctrinarios, quienes al no confiar en la pluralidad social y politica, y creer que su visión de la realidad era la única de las interpretaciones posibles, sintesis del tiempo y las ideas, se negaron, desde dentro del sistema, a institucionalizar el necesario conflicto político y, desde afuera, cerraron las puertas a las demandas de una mayoría social que reclamaba ser representada. Blindados en el idealismo de una estabilidad reducida a inmovilismo y obsesionados por un concepto de sociedad donde la idea de la obediencia asfixiaba todo anhelo de ensanchamiento de la libertad, la dinámica de la Historia se encargó de destruirlos.

69 Joseph Barthélemy, L'introduction du régime parlementaire en France sous Louis XVIII et Charles X, Giard \& Brière, Paris, 1904, p. 1.

70 Dario Roldán, "La inflexión inglesa del pensamiento francés (1814-1848)", Estudios sociales, nº. 26, 2004, pp. 139 y ss. Félix Ponteil, 1848, Armand Colin, París, 1937 (trad. de Jesús Castellote López, La Revolución de 1848, Zyx, Madrid, 1966).

${ }^{71}$ Rosanvallon, El momento Guizot, op. cit., pp. 255 y ss. 


\section{BIBLIOGRAFÍA}

Joan Josep Adrià i Montolio, "La civilización doctrinaria: Guizot y la historia europea (primera parte)", La Torre del Virrey. Revista de estudios culturales, ${ }^{\circ}{ }^{16}$, 2014, pp. 87-110.

Archives philosophiques, politiques et littéraires, Fournier, París, t. II, 1818.

Joseph Barthélemy, L'introduction du régime parlementaire en France sous Louis XVIII et Charles X, Giard \& Brière, París, 1904.

Paul Bénichou, Le sacre de l'écrivain, 1750-1830. Essai sur l'avènement d'un pouvoir spirituel laïque dans la France Moderne, Corti, París, 1973 (trad. de Aurelio Garzón del Camino, La coronación del escritor. Ensayo sobre el advenimiento de un poder espiritual laico en la Francia moderna, Fondo de Cultura Económica, México, 1981).

Paul Bénichou, Le temps des prophètes. Doctrines de l'âge romantique, Gallimard, París, 1977 (trad. de Aurelio Garzón del Camino, El tiempo de los profetas. Doctrinas de la época romántica, Fondo de Cultura Económica, México, 1984).

Guillaume de Bertier de Sauvigny, La Restauration, Flammarion, París, $3^{\mathrm{a}}$ ed., 1974 (trad. al español, La Restauración, Pegaso, Madrid, 1980).

Manuel Carbajosa Aguilera, "Alberto Lista y el origen del gobierno representativo", Revista Internacional de Pensamiento Politico, nº. 11, 2016, pp. 191-211.

Manuel Carbajosa Aguilera, "Los caminos posibles del liberalismo posrevolucionario", Revista Internacional de Pensamiento Politico, $n^{\circ}$. 13, 2018, pp. 195-220.

François-René de Chateaubriand, Réflexions politiques sur quelques écrits du jour et sur les intéréts de tous les Français, Le Normant, París, 1814.

Alberto Clerici, "Contro l'uguaglianza, contro il privilegio. Il giovane Guizot e i suoi critici (1820-1821)", en Giovanni Ruocco y Luca Scuccimarra (coord.), Il governo del popolo. 2.- Dalla Restaurazione alla guerra franco-prussiana, Viella, Roma, 2012, pp. 47-69.

Benjamin Constant, Cours de politique constitutionnelle ou collection des ouvrages publiés sur le gouvernement représentatif, avec une Introduction et des Notes Édouard Laboulaye, Librairie de Guillaumin et Cie., París, t. II, 1861.

Aurelian Craiutu, "The Battle for Legitimacy: Guizot and Constant on Sovereignty", Historical Reflections/Réflexions Historiques, vol. 28, nº. 3, 2002, pp. 471-491.

Aurelian Craiutu, "Introduction" en François Guizot, History of the Origins of Representative Government in Europe, Liberty Fund, Indianápolis, 2002.

Aurelian Craiutu, Liberalism under Siege: The Political Thought of the French Doctrinaires, Lexington Books, Lanham, Maryland, 2003 (trad. al francés de Isabelle Hausser: Le Centre introuvable. La pensée politique des doctrinaires sous la Restauration, Plon, París, 2006).

Francis Démier, La France de la Restauration (1814-1830). L’impossible retour du passé, Gallimard, París, 2012. 
Diario de las Sesiones de Cortes. Congreso de los Diputados, $n^{\circ}$. 13, 4 enero 1849.

Luis Diez del Corral, El liberalismo doctrinario, Centro de Estudios Constitucionales, Madrid, 4ª ed., 1984.

Michael Drolet, "Carrying the banner of the bourgeoisie: Democracy, Self and the Philosophical Foundations to François Guizot's historical and political thought", History of Political Thought, vol. XXXII, nº. 4, winter 2011, pp. 645-690.

Ignacio Fernández Sarasola, "Reseña del libro de François Guizot, Historia de los orígenes del gobierno representativo en Europa, introducción de Ramón Punset, trad. Marceliano Acevedo Fernández, KRK ediciones, Oviedo, 2009, 1024 págs.”, Revista de Estudios Politicos, nº. 153, julio-septiembre 2011, pp. 270-284.

Javier Fernández Sebastián, "La recepción en España de la Histoire de la Civilisation de Guizot", en Jean-René Aymes y Javier Fernández Sebastián (ed.), La imagen de Francia en España (1808-1850), Bilbao-París, Servicio editorial Universidad del País Vasco-Presses de la Sorbonne Nouvelle, 1997, pp. 127-149.

Josep Fontana, De en medio del tiempo. La segunda restauración española, 18231834, Crítica, Barcelona, 2006.

François Guizot, Du gouvernement de la France depuis la Restauration et du ministère actuel, Ladvocat, París, $2^{\mathrm{a}}$ ed., 1820.

François Guizot, Des moyens de gouvernement et d'opposition dans l'état actuel de la France, Ladvocat, París, 1821.

François Guizot, De la démocratie en France, Plon-Víctor Masson, París, 1849 (traducción, introducción y notas de Dalmacio Negro Pavón, De la democracia en Francia, Centro de Estudios Constitucionales, Madrid, 1981).

François Guizot, Histoire des origines du gouvernement représentatif en Europe, 1820, Meline, Cans et Cie., Bruselas, 2 vols., 1851 (trad. en un volumen de Marceliano Acevedo Fernández, Historia de los orígenes del gobierno representativo en Europa, KRK ediciones, Oviedo, 2009).

[François Guizot], Histoire parlementaire de France. Recueil complet des discours prononcés dans les Chambres de 1819 à 1848 par M. Guizot, Michel Lévy Frères, París, t. III, 1863.

François Guizot, "Philosophie politique: De la souveraineté" en François Guizot, Histoire de la civilisation en Europe, présenté par Pierre Rosanvallon, Hachette, París, 1985.

Lucien Jaume, L'individu effacé ou le paradoxe du libéralisme français, Fayard, París, 1997.

Luigi Lacchè, "Constitución, monarquía, parlamento: Francia y Bélgica ante los problemas y modelos del constitucionalismo europeo (1814-1848), Fundamentos: Cuadernos monográficos de Teoría del Estado, Derecho Público e Historia Constitucional, $\mathrm{n}^{\circ}$. 2, 2000, pp. 467-543.

Luigi Lacchè, La Libertà che guida il Popolo. Le Tre Gloriose Giornate del luglio 1830 e le "Chartes" nel costituzionalismo francese, Il Mulino, Bolonia, 2002.

Luigi Lacchè, "Las Cartas otorgadas: la teoría de L'Octroi y las experiencias constitucionales en la Europa post-revolucionaria", Fundamentos: Cuadernos 
monográficos de Teoría del Estado, Derecho Público e Historia Constitucional, nº . 6, 2010, pp. 269-305.

Alain Laquièze, Les origines du régime parlementaire en France (1814-1848), Presses Universitaires de France, París, 2002.

Alberto Lista, "Continúa el discurso sobre la reforma de las costumbres", El Espectador Sevillano, n . 26, 27 de octubre de 1809, pp. 101-103.

Alberto Lista, "Continúa el discurso sobre la reforma de las costumbres", El Espectador Sevillano, n. 27, 28 de octubre de 1809, pp. 105-107.

Alberto Lista, "Prospecto", Gaceta de Bayona, 15 de septiembre de 1828.

Pedro L. López Herraiz, Formar al hombre de Estado. Génesis y desarrollo de la École libre des sciences politiques (1871-1900), Dykinson, Madrid, 2019.

Félix Ponteil, 1848, Armand Colin, París, 1937 (trad. de Jesús Castellote López, La Revolución de 1848, Zyx, Madrid, 1966).

Ramón Punset, "Guizot y la legitimidad del poder" en François Guizot, Historia de los origenes del gobierno representativo en Europa, KRK ediciones, Oviedo, 2009, pp. 13-32.

Antonio Rivera García, Reacción y Revolución en la España liberal, Biblioteca Nueva, Madrid, 2006.

Darío Roldán, "Guizot, Constant y la crítica liberal a la soberanía popular", Libertas, $\mathrm{n}^{\circ}$. 30, 1999, pp. 213-230.

Darío Roldán, "La inflexión inglesa del pensamiento francés (1814-1848)", Estudios sociales. Revista Universitaria Semestral, nº. 26, 2004, pp. 119-142.

Pierre Rosanvallon, La monarchie impossible. Les Chartes de 1814 et de 1830, Fayard, Paris, 1994.

Pierre Rosanvallon, Le moment Guizot, Gallimard, París, 1985 (trad. de Hernán M. Díaz, El momento Guizot. El liberalismo doctrinario entre la Restauración y la Revolución de 1848, Biblos, Buenos Aires, 2015).

Pierre Rosanvallon, "Les Doctrinaires sont-ils des libéraux?", en Darío Roldán (ed.), Guizot, les Doctrinaires et la Presse (1820-1830), Fondation Guizot-Val Richer, París, 1994, pp. 133-139.

Pierre Rosanvallon, Le modèle politique français. La société civile contre le jacobinisme de 1789 à nous jours, Éditions du Seuil, París, 2004 (trad. de Victor A. Goldstein, El modelo politico francés: la sociedad civil contra el jacobinismo, de 1789 a nuestros dias, Siglo XXI Editores, Buenos Aires, 2007).

Raquel Sánchez García, "El liberalismo posrevolucionario", en Pedro Carlos González Cuevas, Ana Martínez Arancón (coords.), Ideas y formas politicas: del triunfo del absolutismo a la posmodernidad, UNED, Madrid, $7^{\text {a }}$ reimpr., 2019, $\left(1^{\mathrm{a}}\right.$ ed., 2010), pp. 223-255.

Maria Luisa Sánchez-Mejía (ed.), Benjamin Constant, Escritos politicos, estudio preliminar, traducción y notas de María Luisa Sánchez-Mejía, Centro de Estudios Constitucionales, Madrid, 1989.

María Luisa Sánchez-Mejía, Benjamin Constant y la construcción del liberalismo posrevolucionario, Alianza, Madrid, 1992. 
Emmanuel de Waresquiel, L'histoire à rebrousse-poil. Les élites, la Restauration, la Révolution, Fayard, París, 2005.

Emmanuel de Waresquiel; Benoît Yvert, Histoire de la Restauration (1814-1830). Naissance de la France moderne, Perrim, París, 1996.

Cheryl B. Welch, Liberty and utility. The French Idéologues and the Transformation of Liberalism, Columbia University Press, Nueva York, 1984.

Enviado el (Submission Date): 04/03/2020

Aceptado el (Acceptance Date): 25/04/2020 